\title{
CEsifo \\ WORKING

\section{Who Gains from Better Access to Credit? Credit Reform and Reallocation of Resources}

Jens Matthias Arnold, Lisandra Flach 


\section{Impressum:}

CESifo Working Papers

ISSN 2364-1428 (electronic version)

Publisher and distributor: Munich Society for the Promotion of Economic Research - CESifo $\mathrm{GmbH}$

The international platform of Ludwigs-Maximilians University's Center for Economic Studies and the ifo Institute

Poschingerstr. 5, 81679 Munich, Germany

Telephone +49 (o)89 2180-2740, Telefax +49 (o)89 2180-17845, email office@cesifo.de

Editors: Clemens Fuest, Oliver Falck, Jasmin Gröschl

www.cesifo-group.org/wp

An electronic version of the paper may be downloaded

- from the SSRN website: $\quad$ www.SSRN.com

- from the RePEc website: $\quad$ www.RePEc.org

- from the CESifo website: www.CESifo-group.org/wp 


\title{
Who Gains from Better Access to Credit? Credit Reform and Reallocation of Resources
}

\begin{abstract}
Brazil's 2005 bankruptcy law reform strengthened creditor protection, resulting in a substantial acceleration of credit expansion and business investment growth. In this paper, we go beyond average effects and examine to what extent the pro-creditor reform affected the allocation of resources across firms. We find evidence that the reform was particularly effective in alleviating credit constraints for high productivity firms. After the reform, better access to credit allowed these firms to thrive on the expense of others. Our results suggest that better access to credit can improve the allocation of resources across firms, thus raising aggregate productivity.
\end{abstract}

JEL-Codes: G330, O160, F120.

Keywords: TFP, credit constraint, credit reform, heterogeneous firms.

Jens Matthias Arnold OECD Economics Department

2 rue André Pascal

France - 75775 Paris Cédex 16

jens.arnold@oecd.org
Lisandra Flach

Department of Economics

University of Munich

Germany - 80539 Munich

lisandra.flach@econ.lmu.de

September 15, 2017

We thank the participants of the RIDGE Forum "Productivity and Growth" 2016 in Rio de Janeiro, 16 ${ }^{\text {th }}$ Workshop "Internationale Wirtschaftsbeziehungen" 2015 in Göttingen, European Trade Study Group 2015, “OECD Seminar” in Paris and "IO and Trade Seminar” in Munich for helpful comments and suggestions. Financial support from the Deutsche Forschungsgemeinschaft through SFB TR15 is gratefully acknowledged. The views reected in this paper are those of the authors and should not be attributed to the OECD or its member countries. 


\section{Introduction}

In many emerging market economies, creditors enjoy comparatively low levels of protection through the legal system (Safavian 2007, Djankov et al. 2008). This reduces lenders' prospects for recovering losses when debtors experience payment difficulties, and in turn reduces lenders' willingness to extend credit. Not surprisingly, creditor protection is generally positively correlated with the development of credit markets across countries. ${ }^{1}$

Several countries have undertaken measures to strengthen creditor protection in an attempt to improve access to finance for enterprises. One example is the bankruptcy law reform introduced in Brazil in 2005, which ensured creditors a more rapid liquidation of distressed firms and allocated higher priority for secured creditors vis-à-vis workers and tax authorities. Following the reform, recovery rates recorded a discrete jump up. Concomitantly, both credit expansion and business investment growth accelerated markedly (see Araujo, Ferreira and Funchal, 2012; Ponticelli and Alencar, 2016).

We use the 2005 reform in Brazil as a source of exogenous variation to investigate the effect on firm productivity and on the allocation of resources across firms. The discrete timing of the reform and the fact that it was largely unanticipated allow estimating a difference-indifferences model. To guide our empirical analysis, we borrow a model with heterogeneous firms and credit constraints from Ponticelli and Alencar (2016).

The model generates two testable predictions that are confirmed using firm-level data. Our results reveal a positive reallocation effect, with stronger benefits from the credit reform accruing to initially high-performing firms. In a falsification exercise where we use only pre-reform data, we find no such effect, which makes it unlikely that we would be simply detecting a pre-existing trend. Appendix B.4 shows several robustness checks.

\section{Theory}

Our empirical results are guided by a theoretical model based on Ponticelli and Alencar (2016), who introduce financial frictions in a Melitz (2003) framework in which firms may choose between producing with high or low technology, as in Bustos (2011). Firms of heterogeneous productivity levels $\varphi$ face fixed costs to invest in a better technology that reduces marginal costs. To adopt the high technology, firms must borrow from financial intermediaries. Whether a given firm can borrow enough to pay this fixed cost depends on the productivity $\varphi$ of the firm and on the strength of creditor protection rights.

\footnotetext{
${ }^{1}$ La Porta et al. (1997) and Djankov et al. (2007) show cross-country evidence that creditor rights are associated with higher credit to GDP ratios, using a creditor rights index that captures the extent to which creditors can control the bankruptcy process.
} 
As in Melitz (2003), firms produce under monopolistic competition and pay a fixed cost $f$ before learning their productivity draw $\varphi$. Labor is the only factor of production. Firms that stay in the market can produce using low technology $l$ or pay an additional fixed cost $\eta$ to produce with high technology $h$, which decreases marginal cost of production by a factor $1 / \gamma$ (see Bustos (2011)). Total cost functions for the low and high technology are $T C_{l}(q, \varphi)=f+\frac{1}{\varphi} q$ and $T C_{h}(q, \varphi)=\eta f+\frac{1}{\gamma \varphi} q$ and profits are $\bar{\pi}_{l}-f$ and $\bar{\pi}_{h}-\eta f$. The unique productivity cutoff $\varphi^{*}$ is determined by the zero profit condition for a firm using the low technology $\pi^{l}\left(\varphi^{*}\right)=0$.

To finance production with high technology, firms must borrow from financial intermediaries. $^{2}$ However, creditors will only lend money if they are guaranteed to be repaid. Thus, the maximum amount a firm can borrow depends on the following incentive compatibility constraint for the firm:

$$
\bar{\pi}_{h}-d \geq \bar{\pi}_{h}-R \bar{\pi}_{h}
$$

The left-hand side represents firm profits after repaying debt $d$ to financial intermediaries. The right-hand side represents the share of profits that cannot be recovered by creditors in case the firm defaults, which reflects the quality of creditors' legal rights $R$. A reform that increases creditor rights will increase the share of firm value that can be recovered.

Hence, the maximum loan size a firm can obtain follows $d^{*}(\varphi)=R \bar{\pi}_{h}$. This equation determines which firms are financially constrained. Since firms must borrow to at least cover the fixed cost $\eta f$ to use the high technology, only firms with $d^{*}(\varphi) \geq \eta f$ are unconstrained, and the cutoff is defined as $\varphi^{u}: d^{*}=\eta f$.

The model generates the following testable implications, both of which have positive implications for aggregate productivity levels of the economy:

Prediction 1 Initially more productive firms reap the greatest productivity benefits from a pro-creditor reform.

The main testable implication from the model refers to the effect of changes in creditors rights following a pro-creditor reform. Because $\frac{\partial \varphi^{u}}{\partial R}<0$, a reform that increases creditors rights lowers the cutoff for being unconstrained $\varphi^{u}$ and allows more firms to use the more efficient technology. The reason for this is that a default has become less attractive and more firms are now better off repaying rather than defaulting on their debt. The firms that are newly benefiting from access to credit due to better creditor rights are those with productivity levels right below the previous cutoff, in other words, they are the best performers among

\footnotetext{
${ }^{2}$ This assumption is used by Ponticelli and Alencar (2016) and is similar to Manova (2013).
} 
the previously credit-constrained firms.

Prediction 2 A reform that increases $R$ reallocates resources towards more productive firms.

Because now more firms can invest in $T C^{h}$ (which is given in units of labour), the reform increases wages and fixed costs. Thus, $\frac{\partial \varphi^{*}}{\partial R}>0$ and $\frac{\partial \varphi^{h}}{\partial R}>0$. In this way, the reform implies an increase in average productivity and a better allocation of resources, as the least productive firms are forced to exit.

\section{Firm-level data and the 2005 reform}

Brazil's 2005 insolvency reform The new bankruptcy legislation introduced in June 2005 was directly aimed at improving creditor rights and firms' access to external finance. The new law upgraded the priority of secured creditors, by giving them preference over tax authorities and limiting the amount paid for each worker. The effects of the new law were highly visible. Recovery rates jumped from almost zero to $12 \%$ within one year and private credit to corporate borrowers rose substantially (Figure 1).

The law is discussed in detail by Araujo and Funchal (2005), who describe how political divisions made it almost impossible to anticipate the final reform package. The exogeneity of the reform and the economic and institutional setting in the periods before and after the reform are discussed in our Appendix B.1.

Figure 1: Recovery rates (left) and the share of corporate private credit over GDP (right). Source: Araujo et al. (2012)
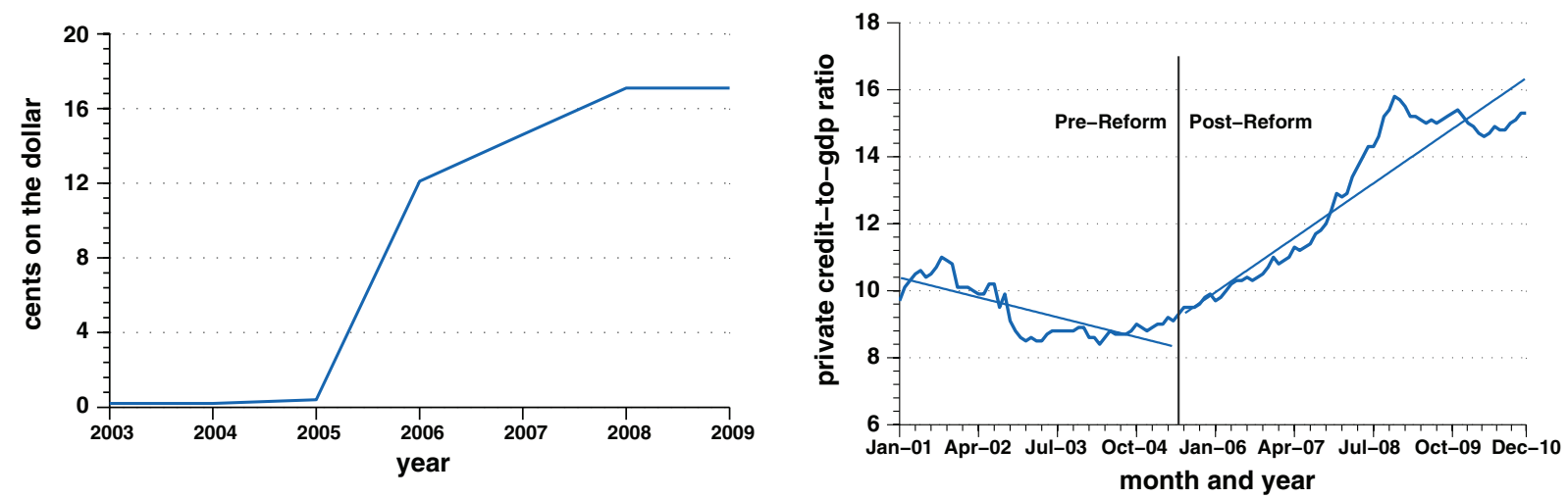

Total factor productivity (TFP) and firm-level data We use firm-level data from the commercially available ORBIS database, published by the private company Bureau van 
Dyke, for the period 2000-2010. We use a representative sample of 1,736 firms, for which we have both annual balance sheet data and basic firm characteristics. ${ }^{3}$ The data is described in Appendix B.2.

We use a TFP index as the main measure of TFP, as described in the Appendix B.3. In robustness checks, we also show results using the residual from the Cobb-Douglas production function (see Appendix B.4).

\section{Empirical strategy and results}

\subsection{Estimating heterogeneous firms responses to the reform}

We are interested in differential effects of the bankruptcy reform on firms with different productivity levels. Hence, we interact a binary variable for the years before and after the

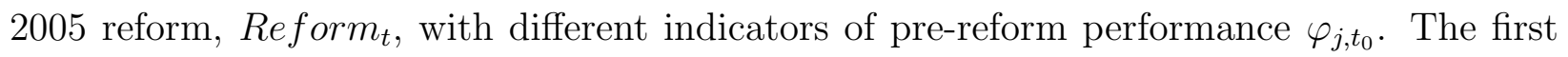
indicator takes the value one for firms whose performance was above the industry-median in the pre-reform years and zero otherwise, called $\varphi_{j, t_{0}}^{\text {med }}$. As an alternative, we also create an indicator for firms that were in the top third of productivity in their respective industry, $\varphi_{j, t_{0}}^{p 33}$. Our basic equation of interest is the following:

$$
T F P_{j t}=\beta_{0}+\beta_{1}\left(\varphi_{j, t_{0}} * \text { Reform } \text { for }_{t}\right)+\kappa_{j}+\rho_{t}+\epsilon_{j t},
$$

where $\kappa_{j}$ are firm fixed effects, $\rho_{t}$ are year fixed effects and $\varepsilon_{j t}$ is an error term. Rather than estimating equation (2) as is, we estimate the equation using a two period model as follows:

$$
\Delta T F P_{j}=\beta_{1} \varphi_{j, t_{0}}+\alpha \ln e m p l_{j, t_{0}}+\vartheta_{i}+\nu_{s}+u_{j}
$$

where $\triangle T F P_{j}$ is the change in TFP between the pre-reform and the post-reform periods. We take simple averages over available observations for 2002-2004 and 2006-2008, respectively.

The two-period model facilitates the interpretation of the results and allows us to deal with issues related to serial correlation and the adjustment of standard errors (see Bertrand et al., 2004). Moreover, it allows us to include fixed effects to control for different trends across industries and states, $\vartheta_{i}$ and $\nu_{s}$. We also control for different productivity growth trajectories across firms of different size using the initial number of employees as a proxy, $\ln \mathrm{empl}_{j, t_{0}}$.

\footnotetext{
${ }^{3}$ For a comparison regarding sample size, Araujo et al. (2012) use a sample of 698 listed firms.
} 
$\beta_{1}$ provides a direct test for the prediction that firms with higher initial productivity $\left(\varphi_{j, t_{0}}=1\right)$ reap stronger productivity benefits from the reform. In fact, the results shown in columns (1) and (2) in Table 1 confirm that $\beta_{1}>0$.

In column 3 , we use another definition of $\varphi$ to shed light on the principal channel through which the hypothesis of stronger firms reaping greater benefits is founded in the model, which is the incidence of credit constraints. We define $\varphi_{j, t_{0}}^{a s s e t s}$ as one for firms that satisfy two conditions: a pre-reform productivity level above the industry-median and a lower ratio of fixed assets to revenues than the industry median. ${ }^{4}$ Also in this case, $\beta_{1}>0$ and is even larger in magnitudes, which reinforces our earlier findings.

Table 1: Effect of the reform on firm productivity

\begin{tabular}{lccc}
\hline $\begin{array}{l}\text { Dependent variable: } \\
\Delta T F P_{j}\end{array}$ & $(1)$ & $(2)$ & $(3)$ \\
\hline$\varphi_{j, t_{0}}^{\text {med }}$ & $0.208^{* * *}$ & & \\
& $(0.0567)$ & & \\
$\varphi_{j, t_{0}}^{p 33}$ & & $0.269^{* * *}$ & \\
& & $(0.0589)$ & \\
$\varphi_{j, t_{0}}^{\text {assets }}$ & & & $0.395^{* * *}$ \\
& & & $(0.0511)$ \\
$\ln$ empl $_{j, t_{0}}$ & $0.0854^{* * *}$ & $0.0659^{* *}$ & $0.0340^{* *}$ \\
& $(0.0256)$ & $(0.0273)$ & $(0.0172)$ \\
\hline Observations & 1,736 & 1,736 & 1,736 \\
R-squared & 0.053 & 0.065 & 0.066 \\
\hline
\end{tabular}

Notes: All estimations include a constant, state and industry fixed effects. Errors are clustered by firm.

$* * *, * *$, and $*$ indicate significance at $1 \%, 5 \%$, and $10 \%$ level.

\subsection{Improvements in the allocation of resources across firms}

A second prediction from the theory is that the credit reform improves the allocation of resources. We use the empirical decomposition of industry-level productivity proposed by Olley and Pakes (1996), as follows:

$$
\omega_{t}=\sum_{j} \mu_{j t} T F P_{j t}=\overline{T F P}_{t}+\sum_{j}\left(\mu_{j t}-\bar{\mu}_{t}\right)\left(T F P_{j t}-\overline{T F P}_{t}\right)
$$

where $\omega_{t}$ is the industry index for industry $i$ and $\mu_{j t}$ are firm market shares.

\footnotetext{
${ }^{4}$ The idea behind this definition is that firms with relatively few fixed assets were at a relative disadvantage prior to the reform, but could have overcome this disadvantage as the assets they could pledge became more valuable to lenders.
} 
The first term $\left(\overline{T F P_{t}}\right)$ represents the unweighted average of TFP. The second term, named covariance term $\Psi_{t}=\sum_{j}\left(\mu_{j t}-\bar{\mu}_{t}\right)\left(T F P_{j t}-\overline{T F P}_{t}\right)$, represents the cross-sectional efficiency of the allocation of activity. The more positive the covariance term, the larger are high-productivity firms, and the higher is allocative efficiency.

To investigate differential effects in credit conditions across industries, we use the standard Rajan and Zingales (1998) measure of the industry dependence on external financing, $F_{i n D e p}$, based on data from US industries. We interact FinDep $p_{i}$ with the post-reform indicator, whereby a higher value of FinDep $p_{i}$ means a higher degree of dependence on external finance. As in equation (2), we estimate the effect of the reform using a first-differenced model:

$$
\Delta \Psi_{i}=\beta_{1} \text { FinDep }_{i}+u_{i}
$$

The identifying assumption underlying equation (5) is that industries $i$ in which firms are more dependent on external finance will be affected stronger by better access to credit. If the latter improves allocative efficiency, we should expect to see larger improvements in industries with stronger dependence on external finance. Hence, we expect that $\beta_{1}>0$.

The positive coefficient for the change in the cross-term $\Psi_{i}$ shown in Table 2 suggests that improvements in allocative efficiency following the reform were more pronounced in

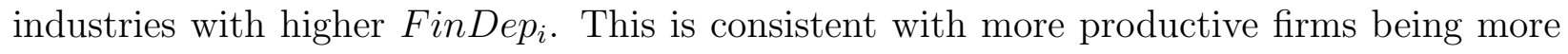
successful in gaining market shares in industries with a higher dependence on external finance following the reform.

Table 2: Effect of the reform on the covariance term $\Delta \Psi_{i}$

\begin{tabular}{lr}
\hline FinDep $_{i}$ & $0.618^{*}$ \\
& $(0.348)$ \\
Observations & 56 \\
R-squared & 0.741 \\
\hline Notes: The estimation includes a constant. ${ }^{*}$ indicate significance at $10 \%$ level. \\
\hline
\end{tabular}

\section{Conclusion}

This paper investigates the heterogeneous responses of firms to a bankruptcy law reform that strengthened creditor rights and lead to an aggregate increase in credit. We find that initially more productive firms are able to reap stronger benefits from the reform. All else equal, this finding suggests that improvements in access to credit would go along with stronger aggregate productivity growth, as high-performing firms become even stronger. Finally, we evaluate 
the impact of the reform on the allocation of resources at the level of industries. Our results point to improvements in allocative efficiency after the reform.

\section{References}

Araujo, A., R. Ferreira, and B. Funchal (2012). The brazilian bankruptcy law experience. Journal of Corporate Finance 18(4), 994-1004.

Arnold, J. M. and B. S. Javorcik (2009). Gifted kids of pushy parents? foreign direct investment and plant productivity in indonesia. Journal of International Economics 79, $42-53$.

Aw, B., X. Chen, and M. Roberts (2001). Firm-level productivity differentials and turnover in taiwanese manufacturing. Journal of Development Economics 66, 51-86.

Bertrand, M., E. Duflo, and S. Mullainathan (2004). How much should we trust differencesin-differences estimates? The Quarterly Journal of Economics 119(1), 249-275.

Bustos, P. (2011). Trade liberalization, exports, and technology upgrading: Evidence on the impact of mercosur on argentinian firms. American Economic Review 11, 304340.

Caves, D. L. and E. Diewert (1982a). The economic theory of index numbers and the measurement of input, output and productivity. Econometrica 50(6), 1393-1414.

Caves, D. L. and E. Diewert (1982b). Multilateral comparisons of output, input and productivity using superlative index numbers. Economic Journal 92, 73-86.

Djankov, S., O. Hart, C. McLiesh, and A. Shleifer (2008). Debt enforcement around the world. Journal of Political Economy 116(6), 1105-1149.

Hsieh, C. and P. Klenow (2009). Misallocation and manufacturing tfp in china and india. Quarterly Journal of Economics 124(4), 1403-1448.

Melitz, M. J. (2003). The impact of trade on intra-industry reallocations and aggregate industry productivity. Econometrica, Econometric Society 71(6), 1695-1725.

Olley, S. and A. Pakes (1996). The dynamics of productivity in the telecommunications equipment industry. Econometrica 64(6), 1263-1297.

Ponticelli, J. and L. Alencar (2016). Court enforcement, bank loans and firm investment: Evidence from a bankruptcy reform in brazil. Quarterly Journal of Economics 131(3), $1365-1413$. 
Rajan, R. and L. Zingales (1998). Financial dependence and growth. American Economic Review 88(3), 559-586.

Safavian, M. and S. Sharma (2007). When do creditor rights work? Journal of Comparative Economics 35(3), 484-508.

\section{A Empirical Appendix}

\section{A.1 Brazil's 2005 insolvency reform: Background and exogeneity}

Prior to 2005, Brazilian bankruptcy law made it very difficult for secured creditors to claim assets pledged as collateral for corporate loans. Creditors' claims were treated as subordinate to both workers and tax authorities, and the liquidation process was slow and ineffective (Araujo et al., 2012), while in reality, a speedy liquidation of remaining assets is often crucial for recovering their fair value.

The new bankruptcy legislation introduced in June 2005 was directly aimed at improving creditor rights and firms' access to external finance. Besides upgrading the priority of secured creditors, under the new law a distressed firm could be now sold before the creditors' list was constituted, which helped to speed up the liquidation process and raise the value of the remaining assets. The law is discussed in detail by Araujo and Funchal (2005).

The exact nature of the new bankruptcy laws took most observers by surprise, which lends significant exogeneity to the reform. Political divisions between fiscal authorities who feared revenue losses and private lenders made it highly doubtful that creditors would obtain seniority relative to tax authorities, for example. As a result of this power struggle, the content of the reform could hardly be anticipated until the final draft was released by the end of 2004 (Ponticelli and Alencar, 2016).

Ponticelli and Alencar (2016) argue that the periods before and after the reform were not characterized by noticeable differences in institutional settings other than the bankruptcy law, which helps for identification. The government of President Luiz Inácio Lula da Silva (Lula) of the Workers' Party took power in 2003, and remained in office until the last year of the sample. To the surprise of many, Lula's economic policies were largely a continuation of those of his social-democrat predecessor, Fernando Henrique Cardoso. Aggregate GDP growth rates were fairly similar around $3.5 \%$ in the periods before and after the reform. In Table A2 we provide summary statistics of some relevant macroeconomic variables over the period. 


\section{A.2 Descriptive Statistics}

Table A1 provides summary statistics for the main variables. Figure A1 shows the distribution of firm size for firms with up to 10,000 employees and reveals a large share of firms with 25 to 500 employees. This share is relatively high in comparison to the structure of the Brazilian economy, which has many small firms. Thus, if there is a bias in our sample, it is towards larger firms. Since larger firms face less financial constraints, our results most likely strengthen the importance of financial constraints for firm productivity.

Table A1: Summary statistics

\begin{tabular}{lcccc}
\hline \multicolumn{1}{c}{ Variable } & Mean & Std. Dev. & Min. & Max. \\
\hline$I\left(\varphi_{j}^{t a}\right)$ & 0.191 & 0.393 & 0 & 1 \\
$I\left(\varphi_{j}^{\text {med }}\right)$ & 0.534 & 0.488 & 0 & 1 \\
$I\left(\varphi_{j}^{\text {p33 }}\right)$ & 0.306 & 0.420 & 0 & 1 \\
$\ln \left(\right.$ Nemployees $\left._{j, t_{0}}\right)$ & 5.05 & 1.762 & 1.61 & 11.222 \\
$\ln \left(\right.$ Age $\left._{j, t_{0}}\right)$ & 2.95 & 0.642 & 0.693 & 4.934 \\
FinDep $_{i}$ & 0.448 & 0.097 & 0.2 & 0.77 \\
\hline
\end{tabular}

Table A2: Summary statistics - macroeconomic variables

\begin{tabular}{lccc}
\hline Variable & $\mathbf{2 0 0 3}$ & $\mathbf{2 0 0 5}$ & $\mathbf{2 0 0 8}$ \\
\hline Bank lending deposit spread & 45.11 & 37.75 & 35.59 \\
Exchange rate R $\$$ US\$ & 3.08 & 2.43 & 1.83 \\
GDP growth (\%) & $1.14^{*}$ & 3.2 & 5.09 \\
Interest rate (SELIC \%, yearly average) & 22.9 & 19.14 & 12.5 \\
Export coefficient (exports with respect to domestic production) & 12.9 & 12.8 & 9.3 \\
Import coefficient (imports with respect to domestic production) & 17 & 19.2 & 26.6 \\
Investment - Fixed capital formation, \% change in proportion to GDP & & & \\
infrastructure & 3.3 & 3.5 & 5.4 \\
intermediate and capital goods & 1.4 & 1.7 & 1.9 \\
consumer goods & 2.9 & 3.0 & 3.7 \\
natural resources & 2.6 & 2.8 & 3.3 \\
\hline Notes: * In 2002, GDP growth was of 3.05\% and in 2004 5.76\%. & & \\
Sources: Brazilian Central Bank and IPEAdata. & & & \\
\hline
\end{tabular}

We compute the degree of firm heterogeneity within industries in terms of the productivity dispersion and the covariance between firm size and productivity. Given that measurement issues generally affect cross-industry comparisons, we avoid these issues by focusing on within-industry measures of dispersion and covariance. Figure A2 reports the coefficient of variation of TFP within-industries and reveals large dispersion in TFP within industries. Moreover, the dispersion varies significantly across industries. As argued by Hsieh and 
Figure A1: Distribution of firm size

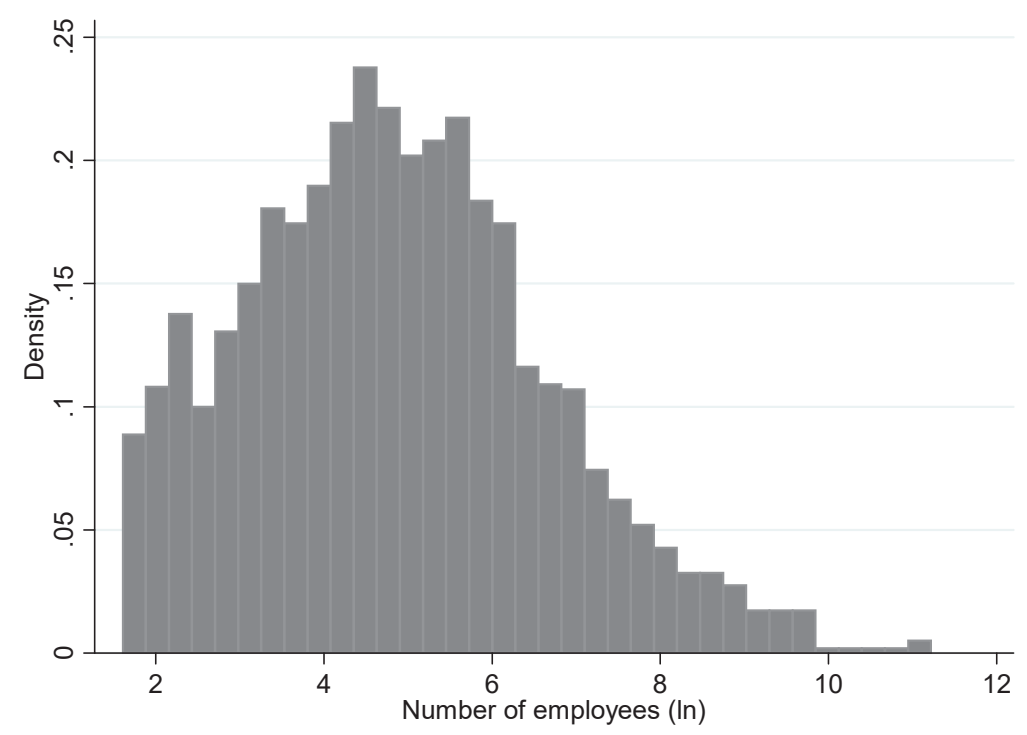

Klenow (2009), higher dispersion of firm productivity within an industry may reflect greater misallocation of resources.

Figure A2: Coefficient of variation of TFP, by industry

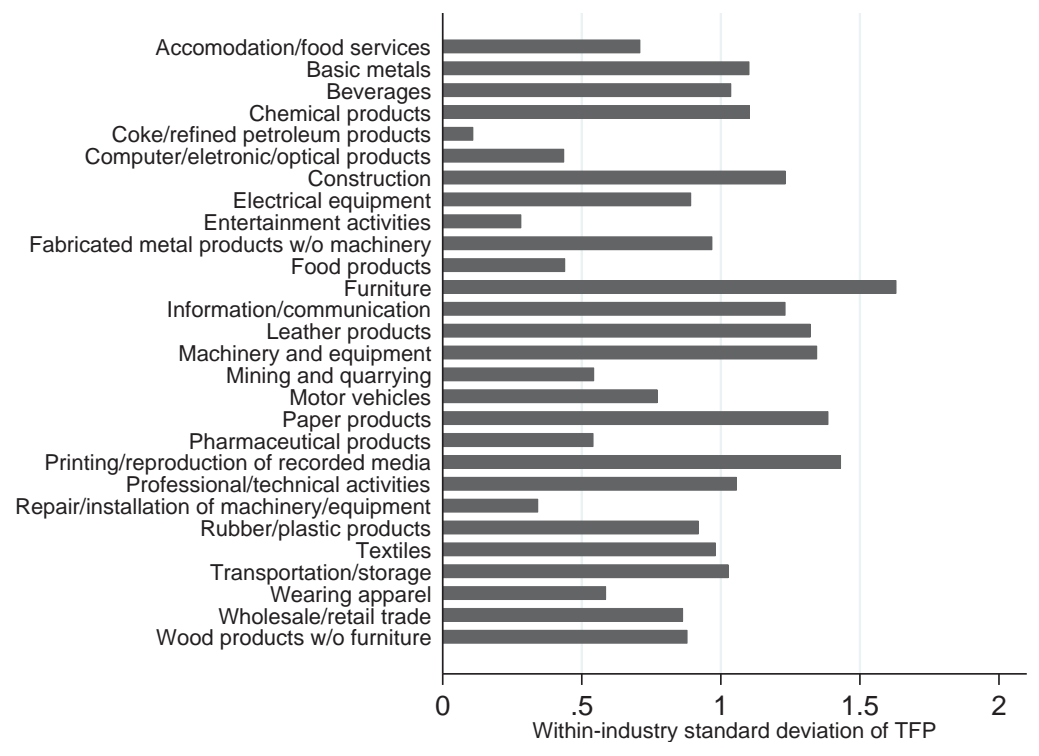




\section{A.3 TFP Estimation}

We estimate total factor productivity (TFP) using a multilateral index suggested by Aw, Chen and Roberts (2001), which builds on Caves and Diewert (1982a) and Caves and Diewert (1982b). It allows for consistent comparisons of TFP in firm-level data with a panel structure. ${ }^{5}$ To guarantee that comparisons between any two plant-year observations are transitive, the index expresses each individual plant's output and inputs as deviations from a reference firm, which employs geometric means of logarithmic inputs and logarithmic output and of input costs shares.

Value added is used as the output measure, with two input factors labour and capital. Nominal values are deflated using industry-specific deflators at the 2-digit level and a capital deflator.

The TFP index for firm $\mathrm{j}$ in industry $\mathrm{i}$ at time $\mathrm{t}$ as follows:

$$
T F P_{j t}=\ln Y_{j t}-\overline{\ln Y_{t}}-\frac{1}{2} \sum_{n}\left(\sigma_{j}^{n}-\overline{\sigma_{i}^{n}}\right)\left(\ln x_{j t}^{n}-\overline{\ln x_{t}^{n}}\right),
$$

where $Y$ is value added, $x^{n}$ is the use of factor $n$, upper bars indicate geometric means across all firms in the same 2 -digit industry $i$. In the same vein, $\sigma_{j}^{n}$ is the cost share of factor $n$ in the revenues of firm $j$, while $\overline{\sigma_{i}^{n}}$ is the geometric mean cost share in industry $i$ in year $t$. In our case with two factors labour and capital, we use the identifying assumption $\sigma_{j}^{1}+\sigma_{j}^{2}=1$, which is equivalent to assuming constant returns to scale. The index is calculated separately for each of 2-digit industry. More information on the variables used for measuring TFP are described in the appendix.

\section{A.4 Robustness checks}

Distribution functions of TFP growth pre-reform and post-reform Our basic finding can be illustrated in a simple picture. Figure A3 depicts the distribution functions of TFP growth between the pre-reform and post-reform periods, for firms that were initially strong performers and those that were not. This simple graphic analysis uses the same definition for high-performing firms as in column 1 of Table 1. It cannot account for the fixed effects and covariates we control for in the regression analysis, but even the raw data clearly confirm the stronger productivity growth of initially better performing firms. In fact, the

\footnotetext{
${ }^{5}$ This approach allows for flexible and heterogeneous production technology, and has also been used, for instance, in Arnold and Javorcik(2009) and Griffith et al. (2004). A comparison of the robustness of five widely used productivity measures (index numbers, data envelopment analysis, stochastic frontiers, GMM and semiparametric estimation) suggests that the approach we chose tends to produce very robust results across the different experiments (see Van Biesebroeck, 2007).
} 
cumulative density function of the strong performers dominates the one for low performers at all points.

Figure A3: TFP gains between pre-reform and the post-reform periods

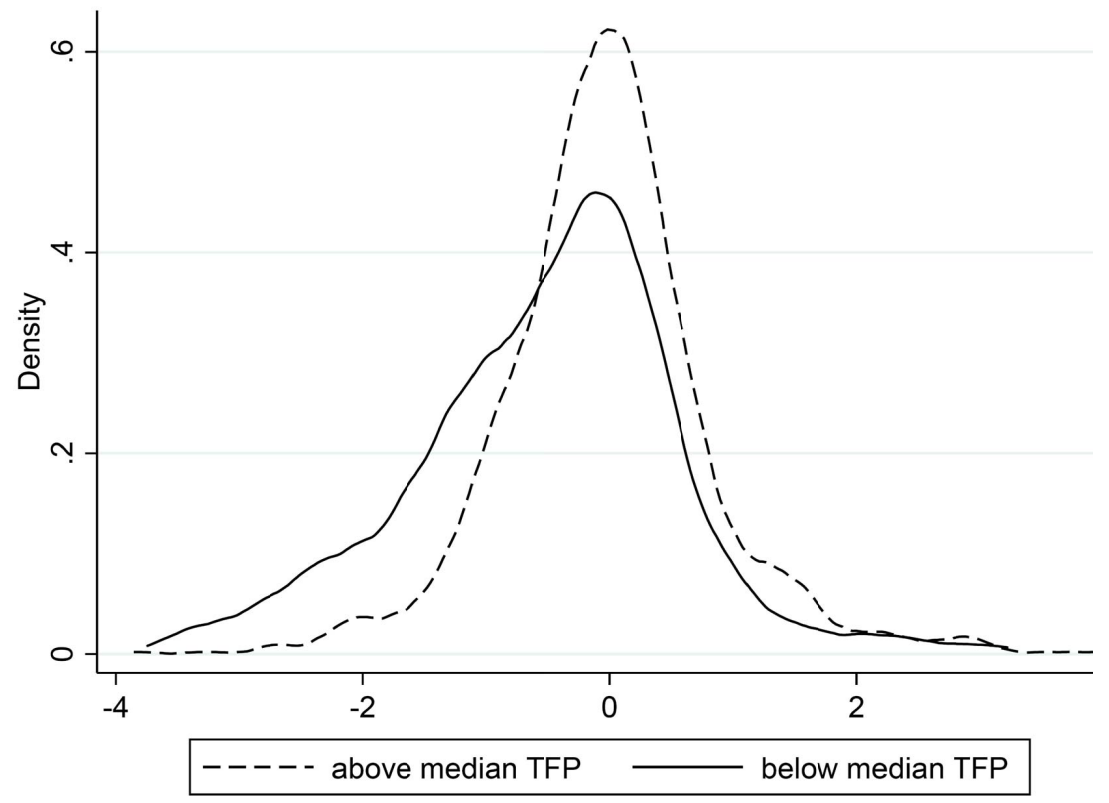

Falsification exercise using only pre-reform data Our estimations of heterogeneous firm responses to the reform already control for systematic differences with respect to productivity growth, not only levels, across industries and states, as well as the effects of initial firm size on TFP growth, but it is nonetheless conceivable that pre-existing trends related to initially strong performance would be creating a bias in our estimations of equation (2). In other words, firms that did well at the beginning and that are not well-captured by industry or state dummies may have been on a trajectory of strong TFP growth, independently of the credit reform. In order to investigate to what extent such correlations between levels and growth of TFP may be present in our data, we replicate our regressions using only data from the pre-reform period, i.e. between 2002 and 2004. In the absence of the reform, we detect no change in TFP for the initially more productive firms (Table A3). ${ }^{6}$

\footnotetext{
${ }^{6}$ Note that we do not observe firms in all years before and after the reform. This explains the restricted number of observations when we consider only the years 2002 and 2004.)
} 
Table A3: Effect of the reform on firm productivity - falsification exercise

\begin{tabular}{|c|c|c|c|}
\hline $\begin{array}{l}\text { Dependent variable: } \\
\Delta T F P_{j}\end{array}$ & (1) & $(2)$ & $(3)$ \\
\hline$\varphi_{j, t_{0}}^{\text {med }}$ & $\begin{array}{l}-0.0295 \\
(0.109)\end{array}$ & & \\
\hline$\varphi_{j, t_{0}}^{p 33}$ & & $\begin{array}{l}-0.0690 \\
(0.0540)\end{array}$ & \\
\hline$\varphi_{j, t_{0}}^{a s s e t s}$ & & & $\begin{array}{c}-0.0136 \\
(0.117)\end{array}$ \\
\hline $\ln e m p l_{j, t_{0}}$ & $\begin{array}{l}0.0225^{*} \\
(0.0130)\end{array}$ & $\begin{array}{l}0.0245^{*} \\
(0.0131)\end{array}$ & $\begin{array}{c}0.0180 \\
(0.0117)\end{array}$ \\
\hline Observations & 341 & 341 & 341 \\
\hline R-squared & 0.192 & 0.191 & 0.189 \\
\hline $\begin{array}{l}\text { Notes: All estimation } \\
\text { fixed effects. Errors } \\
* * *, * * \text {, and }{ }^{*} \text { indica }\end{array}$ & $\begin{array}{l}\text { s include a } \\
\text { re clustere } \\
\text { e significa }\end{array}$ & $\begin{array}{l}\text { constant, } \\
\text { d by firm. } \\
\text { ace at } 1 \% \text {, }\end{array}$ & $\begin{array}{l}\text { and industry } \\
\text { and } 10 \% \text { level. }\end{array}$ \\
\hline
\end{tabular}

Results using an alternative measure of TFP As an additional robustness check, we repeat our baseline estimations using an alternative measure of TFP, estimated as the residual from simple industry-level OLS regressions of a Cobb-Douglas production function. The production functions use value added as the dependent variable with capital $\left(K_{j t}\right)$ and labor $\left(L_{j t}\right)$ as production factors: $Y_{j t}=\nu_{i}+\alpha L_{j t}+\beta K_{j t}+u_{j t}$. Our earlier findings carry through when using this alternative approach to measuring TFP, as shown in Table A4.

Table A4: Effect of the reform on firm productivity - Cobb-Douglas residual

\begin{tabular}{|c|c|c|c|}
\hline $\begin{array}{l}\text { Dependent variable: } \\
\Delta \text { TFP Cobb-Douglas }\end{array}$ & (1) & $(2)$ & $(3)$ \\
\hline$\varphi_{j, t_{0}}^{\text {med }}$ & $\begin{array}{c}0.0949^{* * *} \\
(0.0291)\end{array}$ & & \\
\hline$\varphi_{j, t_{0}}^{p 33}$ & & $\begin{array}{c}0.108^{* * *} \\
(0.0302)\end{array}$ & \\
\hline$\varphi_{j, t_{0}}^{t a}$ & & & $\begin{array}{c}0.182^{* * *} \\
(0.0593)\end{array}$ \\
\hline Observations & 0.061 & 0.064 & 0.065 \\
\hline R-squared & 1,723 & 1,723 & 1,723 \\
\hline $\begin{array}{l}\text { Notes: All estimations } \\
\text { fixed effects. Errors ar } \\
* * *, * * \text {, and } * \text { indicate }\end{array}$ & $\begin{array}{l}\text { nclude a co } \\
\text { clustered b } \\
\text { ignificance }\end{array}$ & $\begin{array}{l}\text { stant, stat } \\
\text { firm. } \\
\text { t } 1 \%, 5 \% \text {, }\end{array}$ & $\begin{array}{l}\text { nd industry } \\
\text { d } 10 \% \text { level. }\end{array}$ \\
\hline
\end{tabular}

Results using sales growth Finally, we investigate the effect of the reform on another and simpler measure of firm performance, sales growth $\left(\Delta \ln\right.$ Sales $\left._{j}\right)$. If resources are better 
allocated following the reform, we could expect that better firms grow more in terms of sales. Table A5 reports the results for equation (2) using $\Delta \ln$ Sales $_{j}$ as the dependent variable. In all columns, the results reveal a positive and significant effect for the initially high-performing firms, which reinforces the argument of reallocation of resources towards more productive firms.

Table A5: Effect of the reform on firm size, measured by sales

\begin{tabular}{|c|c|c|c|}
\hline $\begin{array}{l}\text { Dependent variable: } \\
\Delta \ln \text { Sales }_{j}\end{array}$ & (1) & $(2)$ & (3) \\
\hline$\varphi_{j, t_{0}}^{m e d}$ & $\begin{array}{l}0.0449^{*} \\
(0.0237)\end{array}$ & & \\
\hline$\varphi_{j, t_{0}}^{p 33}$ & & $\begin{array}{c}0.0493^{* *} \\
(0.0243)\end{array}$ & \\
\hline$\varphi_{j, t_{0}}^{t a}$ & & & $\begin{array}{c}0.0502^{* *} \\
(0.0243)\end{array}$ \\
\hline Observations & 0.093 & 0.092 & 0.095 \\
\hline R-squared & 1,733 & 1,733 & 1,733 \\
\hline $\begin{array}{l}\text { Notes: All estimation } \\
\text { fixed effects. Errors } \\
* * *, * * \text {, and } * \text { indica }\end{array}$ & $\begin{array}{l}\text { s include a } \\
\text { re clustere } \\
\text { e significa }\end{array}$ & $\begin{array}{l}\text { constant, } \\
\text { d by firm. } \\
\text { ace at } 1 \% \text {, }\end{array}$ & $\begin{array}{l}\text { and industry } \\
\text { and } 10 \% \text { level. }\end{array}$ \\
\hline
\end{tabular}

